\title{
Strategi Kreatif Kerajinan Payung Muto Menjadikan Desa Tanjung sebagai Desa Wisata di Klaten - Jawa Tengah
}

\author{
Likha Sari Anggreni ${ }^{1}$, Ina Primasari ${ }^{2}$, C.H.D. Surwati ${ }^{3}$, Prahastiwi Utari ${ }^{4}$, Tanti Hermawati ${ }^{5}$ \\ 1,3,4,5 Universitas Sebelas Maret, Surakarta - Indonesia \\ ${ }^{2}$ Sekolah Vokasi Universitas Sebelas Maret, Surakarta - Indonesia
}

\begin{abstract}
ABSTRAK
Pengembangan desa wisata menjadi salah satu cara yang dapat ditempuh untuk memberdayakan masyarakat dan meningkatkan perekonomian desa. Kearifan lokal yang dimiliki masing-masing desa menjadi potensi yang dapat berkembang secara optimal dan bermanfaat bagi masyarakat. Desa Tanjung, Juwiring, Klaten menjadi salah satu daerah yang sedang merintis pembangunan desa wisata dengan industri payung lukis muto sebagai produk utamanya. Untuk mencapai kesuksesan, masyarakat setempat wajib menerapkan perencanaan dan pengelolaan yang strategis. Penelitian ini menganalisis masalah yang berkaitan dengan pariwisata di Desa Wisata Tanjung, yaitu desa wisata ini belum melakukan pemasaran yang optimal, dan kemudian menemukan solusinya dengan menyusun strategi kreatif dan media sebagai suatu strategi promosi yang diejewantahkan dalam integrated marketing communication (IMC). Penelitian ini diharapkan dapat dijadikan sebagai rujukan dalam implementas perwujudan Desa Wisata Tanjung Kecamatan Juwiring
\end{abstract}

Kata Kunci: desa wisata; kerajinan 1aying muto; strategi kreatif; media; IMC

\section{Creative Strategies on Muto Umbrella Crafts in Realizing Tanjung Village as Tourism Village in Klaten - Central Java}

\begin{abstract}
The development of a tourism village is one of many options for empowerment of the community and improving the village economy. The local wisdom possessed by each village is a potential that can optimally develop and benefit the community. Tanjung Village, Juwiring, Klaten is one of the areas that is pioneering the development of a tourist village with the Muto painting umbrella industry as its main product. To achieve success, local communities are obliged to implement strategic planning and management. This research analyzes problems related to tourism in Tanjung Wisata Village, which is this tourism village has not done optimal marketing, and then finds a solution by planning for creative strategies and media as a promotional strategy embodied in integrated marketing communication (IMC). This research is expected to be used as a reference in the implementation of the Tanjung Wisata Village, Juwiring District.
\end{abstract}

Keywords: tourism village; muto umbrella craft; creative strategy; media; IMC 


\section{PENDAHULUAN}

Berdasarkan Laporan Kinerja Kementerian Pariwisata dan Ekonomi Kreatif tahun 2018, kontribusi sektor pariwisata terhadap Pendapatan Domestik Bruto (PDB) sebesar 5,25 persen. Angka tersebut mengalami kenaikan sejak 2015 sebesar satu persen dari tahun-tahun sebelumnya 4,25 persen. Pada tahun yang sama, realisasi investasi sektor pariwisata mencapai 1,6 miliar dolar AS atau 80,43 persen dari target dua miliar dolar AS. Devisa pada sektor pariwisata mencapai Rp229,5 triliun, meningkat 15,4 persen secara tahunan.

Penyerapan tenaga kerja sektor pariwisata pun meningkat. Data Kemenparekraf menunjukkan penyerapan tenaga kerja pada sektor pariwisata meningkat sekitar 10 persen dari jumlah penduduk atau sekitar 12,7 juta. Lubis dan Osman (2014) menyebutkan pariwisata dapat menghasilkan pertumbuhan ekonomi di Asia, termasuk di Asia Tenggara dan secara khusus di Indonesia. Sektor pariwisata juga dapat menstimulus berbagai sektor produksi, juga memberikan kontribusi secara langsung bagi kemajuan-kemajuan dalam usaha-usaha pembuatan serta perbaikan pelabuhan dan jalan raya, berkontribusi dalam pelaksanaan program kebersihan dan kesehatan, proyek sarana budaya, pelestarian lingkungan hidup dan sebagainya yang dapat memberikan keuntungan dan kesenangan baik kepada masyarakat setempat maupun wisatawan dari luar (Subagyo, 2012).

Suryanti (2013) menyatakan sektor pariwisata Indonesia memiliki potensi besar yang bisa terus dikembangkan. Perkembangan pariwisata di Indonesia terjadi cukup pesat serta mengalami banyak perubahan terutama dalam konsep dan tujuan berwisata. Wisatawan tidak hanya menikmati keindahaan alam tempat wisata dengan segala fasilitas wisatanya namun juga ingin menikmati pariwisata berinteraksi secara langsung dengan lingkungan serta masyarakat lokal. Perubahan stigma masyarakat inilah yang mendorong muculnya konsep pariwisata pedesaan yang ditandai dengan munculnya desa-desa wisata di berbagai provinsi di Indonesia.

Kementerian Pariwisata dan Ekonomi Kreatif (Kemenparekraf) menargetkan Indonesia dapat memiliki 2.000 desa wisata pada akhir tahun 2019. Program desa wisata ini ditujukan untuk desa dengan potensi wisata yang memiliki kriteria alam, budaya, dan kreatif serta memiliki kisah yang dapat diceritakan. Program desa wisata ini dilakukan untuk mengoptimalkan potensi wisata yang dimiliki Indonesia dan sebagai upaya perbaikan taraf ekonomi masyarakat secara kolektif karena pengelolaan desa wisata yang dilakukan secara bersamasama dengan komunitas masyarakat daerah setempat.

Desa wisata didefinisikan beragam. Salah satu pemahaman mengenai wisata desa dikemukakan oleh Suyanti (2013) yaitu suatu bentuk lingkungan yang memiliki ciri khusus, baik alam maupun budaya yang sesuai dengan tuntutan wisatawan, di mana mereka dapat menikmati mengenal, menghayati dan mempelajari kekhasan desa beserta segala daya tariknya. Untuk menyukseskan program desa wisata, selain dibutuhkan potensi wisata yang unik dan berbeda dari yang lain, hal yang juga penting dilakukan adalah menciptakan brand awareness kepada publik agar mereka tahu keberadaan desa wisata tersebut. Hal ini penting karena tingkat brand awareness publik terhadap suatu produk akan menjadi salah satu penentu keberhasilan promosi dan pemasaran. Brand atau merek yang tidak dikenal biasanya 
hanya mempunya sedikit peluang untuk menarik calon konsumen dan niat pembelian dapat ditingkatkan dengan peningkatan brand awareness (Malik, 2013).

Brand awareness, menurut Hermawan (2012), adalah kemampuan dari seseorang calon pembeli (potential buyer) untuk mengenali (recognize) atau mengingat (recall) suatu merek yang merupakan bagian dari suatu kategori produk. Kemampuan konsumen untuk mengenal dan mengingat brand berperan besar dalam keputusan seseorang untuk membeli barang. Perusahaan yang baru berdiri pasti menginginkan merek produk yang mereka ciptakan dapat dikenal dan diterima oleh konsumen. Perusahaan yang sudah menjalankan bisnisnya sejak lama tidak boleh berpuas diri karena persaingan bisnis saat ini semakin rumit. Membangun brand awareness, yang termasuk bagian dari kegiatan komunikasi pemasaran menjadi salah satu langkah awal yang harus ditempuh oleh desa wisata agar objek wisata yang mereka tawarkan dapat dikenali oleh masyarakat.

Tidak bisa dipungkiri, kegiatan pemasaran seringkali menjadi kendala dari para pelaku usaha desa wisata. Padahal, pengimplementasian komunikasi pemasaran menjadi salah satu point penting dalam kepariwisataan. Hal ini sejalan dengan pendapat Mihart (2012) dan Rehman (2011) yang menyebutkan komunikasi pemasaran akan berdampak pada perilaku konsumen, dan bagaimana proses pengambilan keputusan konsumen tersebut. Untuk memasarkan desa wisata, diperlukan pengimplementasian komunikasi pemasaran melalui strategi kreatif dan pemanfaatan media yang strategis agar pesan yang disampaikan diterima dan berhasil mempersuasi calon konsumen.

Strategi kreatif merupakan jalan yang dapat ditempuh untuk melakukan penetrasi pesan terhadap para calon konsumen sehingga calon konsumen akan terhindar dari over communicated. Strategi kreatif sendiri berdiri dengan pondasi rencana pemasaran dan komunikasi; hasil penelitian tentang konsumen sasaran; data tentang produk; persaingan di pasar; dan rencana dasar strategi media (Christoper Gilsaon dan Bergman, 1980). Pengimplementasian strategi kreatif yang tepat akan memberikan dampak positif bagi brand, seperti menjadikannya top of mind atau bahkan memiliki market share yang luas.

Selain strategi kreatif, menentukan media yang akan digunakan juga menjadi poin penting dalam pelaksanaan komunkasi pemasaran. Media, menurut Kamus Besar Bahasa Indonesia (KBBI) dapat diartikan sebagai alat atau sarana komunikasi. Dalam hal pemasaran, media yang sering digunakan ialah media massa baik yang berbentuk cetak, elektronik, maupun media daring. Pemanfaatan media dalam komunikasi pemasaran baiknya dilakukan secara intensif dan tepat sasaran sesuai dengan target konsumen yang telah ditetapkan. Mengkombinasikan berbagai jenis media dalam memasarkan suatu produk, dalam hal ini ialah desa wisata, juga dapat menjadi strategi yang tepat untuk menarik minat calon konsumen dengan jangkauan yang lebih luas.

Pengimplementasian strategi kreatif dan media dalam pengembangan desa wisata dapat diejawantahkan melalui konsep integrated marketing communication (IMC) atau komunikasi pemasaran terpadu. IMC adalah koordinasi dan integrasi dari semua alat pemasaran komunikasi, cara, dan sumber di suatu perusahaan yang dirancang untuk memaksimalkan dampak pada pelanggan dan pengguna akhir lain dengan biaya seminimal mungkin (Baack \& Keneth, 2012). IMC merupakan proses pengembangan dan implementasi berbagai bentuk 
program komunikasi persuasif kepada pelanggan atau calon pelanggan, kemudian berbalik pada perusahaan atau industri untuk menentukan dan mendefinisikan bentuk dan metode yang perlu dikembangkan bagi program komunikasi yang persuasif menjadi salah satu cara untuk mengembangkan strategi kreatif dan media yang paling tepat karena dapat menggunakan alat dan medium komunikasi yang beragam.

Komunitas masyarakat Desa Tanjung Kecamatan Juwiring, Kabupaten Klaten merupakan salah satu komunitas yang tengah merintis desa wisata. Akan tetapi, selama proses perwujudannya, desa wisata ini mengalami kesulitan dalam hal pemasaran yang berakibat pada stagnasi atau bahkan penurunan jumlah pengunjung, serta belum terbentuk brand awareness terhadap desa wisata ini pada masyarakat luas. Kecamatan Juwiring merupakan salah satu kecamatan di wilayah Kabupaten Klaten yang terkenal dengan kerajinan payung lukis yang dinamai payung muto.

Ada tiga desa yang produktif menghasilkan payung lukis tersebut, yaitu Tanjung, Kenaiban, dan Kwarasan. Kerajinan payung hias di Kecamatan Juwiring sudah ada sejak masa kolonial Belanda. Hal itu berpengaruh pada pola hias payung, yakni memiliki motif gelap dan polos. Seiring perkembangan zaman, pola hias kerajinan ikut berubah dan menjadi lebih variatif dengan warna-warna yang cerah. Kerajinan tangan payung hias berbahan kertas ini telah bertahun-tahun digunakan Keraton Yogyakarta, Solo dan masyarakat Bali dalam upacara keagamaan. Payung ini juga digunakan untuk acara pameran besar, dekorasi pernikahan dan panggung, hotel, hingga kafe. Kerajinan payung yang dimiliki oleh Kecamatan Juwiring merupakan warisan yang mengandung unsur nilai dan budaya.

Akan tetapi, kerajinan payung hias yang telah eksis sejak lama ini perlahan-lahan mulai meredup. Penyebabnya adalah krisis moneter yang sempat dialami Indonesia pada tahun 1998, serta adanya perbedaan skala produksi antara pengrajin besar dan pengrajin kecil, membuat pengrajin kecil susah mendapatkan pasokan bahan baku serta hanya dapat menjual hasil kerajinan dengan harga rendah yang berimbas pada tidak adanya peningkatan ekonomi dari para pengrajin. Tidak adanya generasi penerus pengrajin juga menjadi permasalahan lainnya. Menurunnya minat dan pemesanan membuat para pengrajin beralih profesi. Saat ini hanya terdapat 50 orang yang masih menekuni kerajinan payung lukis.

Juwiring memiliki potensi yang besar pada bidang kepariwisataan, terutama dari segi wisata budaya berupa kerajinan payung muto. Lokasi industri kerajinan payung Juwiring yang dikelilingi oleh area persawahan menghadirkan suasana desa dengan alam yang asri, bisa menambah daya tarik untuk desa wisata ini. Akses yang mudah juga menjadi nilai tambah bagi Desa Wisata Juwiring. Dengan begitu, tidak hanya memiliki kerajinan payung hias yang indah dan unik, Desa Wisata Juwiring juga dapat dikembangkan sebagai kawasan agrowisata dengan memanfaatkan lahan pertanian yang ada disekitarnya.

Apabila dipadukan dan dikelola dengan baik, Kecamatan Juwiring bisa menjadi desa wisata yang sukses karena memiliki daya tarik wisata budaya lewat kerajinan payung hias dan daya tarik alam lewat area persawahan yang asri. Jika potensi ini tidak dilestarikan dan dikembangkan maka potensi ini akan hilang. Untuk mengoptimalkan potensi Desa Wisata Tanjung, diperlukan model pengelolaan dan pemasaran yang lebih baik dengan 
mengimplementasikan IMC sebagai strategi kreatif dan media untuk mengenalkan dan meningkatkan brand awareness Desa Wisata ini ke khalayak luas.

Berdasarkan pemaparan di atas, penulis tertarik menyusun konsep IMC dalam mewujudkan Desa Wisata Tanjung Kecamatan Juwiring dengan identifikasi masalah: "Bagaimana konsep implementasi IMC dalam mewujudkan Desa Wisata di Desa Tanjung Kecamatan Juwiring?" Tujuannya adalah menyusun strategi kreatif dan media pada kerajinan payung muto dan Desa Wisata Tanjung melalui konsep komunikasi terapan terpadu sebagai rujukan dalam implementasi perwujudan Desa Wisata Tanjung Kecamatan Juwiring.

Pemasaran menggunakan strategi periklanan, menurut Charles (2013), strategi kreatif dan eksekusi iklan menjadi hal yang sangat menentukan agar pengiklan atau produsen dapat dengan tepat menyampaikan pesan pada sasaran juga termasuk bagaimana membuat konten dan mempresentasikannya. Aspek terpenting dalam kampanye iklan, strategi kreatif didefinisikan sebagai panduan dasar dalam menentukan sifat umum dan karakter dari pesan yang akan dirancang. Hal tersebut yaitu mewujudkan tema, positioning, dan titik fokus pesan. Dalam kata lain, eksekusi ini berarti menentukan daya tarik iklan, copy, dan ilustrasi untuk memilih strategi kreatif. Pemilihan gambar, ukuran, warna, general layout, captioning, dan penggunaan teks merupakan elemen utama dalam eksekusi.

Strategi kreatif memfokuskan pada apa dan bagaimana suatu pesan akan dikomunikasikan dalam sebuah pemasaran. Strategi kreatif juga sering dianggap sebagai hasil terjemahan dari berbagai informasi mengenai produk, pasar, dan target konsumen, ke dalam suatu posisi tertentu di dalam komunikasi yang kemudian dapat dipakai untuk merumuskan tujuan iklan (Kasali, 1995).

Menurut Gilson dan Berkman (dalam Kasali, 1995), proses perumusan strategi kreatif terdiri atas tiga tahap yaitu: (1) mengumpulkan dan mempersiapkan informasi pemasaran yang tepat agar dapat menemukan strategi kreatif; (2) membenamkan diri ke dalam informasiinformasi untuk menetapkan suatu posisi atau platform dalam penjualan serta menentukan tujuan iklan yang akan dihasilkan. Pada tahap inilah seluruh ide dan proses perumusan strategi kreatif terjadi; (3) melakukan presentasi di hadapan pengiklan atau pihak terkait untuk memperoleh persetujuan sebelum rancangan iklan dipublikasikan melalui mediamedia yang telah ditetapkan.

Media merupakan alat penyalur informasi atau pesan antara komunikator dengan komunikan. Media dapat dikatakan sebagai segala bentuk dan saluran yang dipakai oleh individu/kelompok untuk menyampaikan pesan. la memegang peran penting dalam mengkomunikasikan informasi kepada penerima (Happer \& Philo, 2013). Dengan demikian, media tidak lepas dari proses komunikasi yang terjadi dalam kehidupan sehari-hari.

Saat ini, media memiliki jenis yang beragam dan terus mengalami perkembangan dari masa ke masa. Jenis media tersebut memiliki fungsi dan karakternya masing-masing dan berbeda satu sama lain. Brets (2008) menyebutkan, terdapat tiga jenis media: 
(1) media Audio, jenis media yang melibatkan indera pendengaran dalam proses penyampaian pesan. Pesan yang dapat disampaikan dalam media audio adalah pesan verbal (kata-kata dan bahasa lisan lain) dan pesan nonverbal (musik, vokalisasi, dan bunyi lainnya);

(2) media visual, jenis media yang melibatkan indera penglihatan. Beberapa media visual adalah media visual verbal yang berisi pesan verbal atau pesan linguistik berbentuk tulisan, misalnya buku, majalah, surat kabar, dan lainnya; media visual grafis berisi pesan non-verbal berupa simbol-simbol atau unsur-unsur grafis, misalnya sketsa, foto, gambar, diagram, peta, dan lainnya;

(3) media visual non cetak yang berisi pesan dalam bentuk tiga dimensi, misalnya diorama, miniatur, model, mock up, dan specimen; media audio visual yang melibatkan indera pendengaran dan indera penghlihatan secara bersamaan dalam satu proses. Pesan yang disalurkan pada jenis media ini bersifat verbal dan non-verbal. Misalnya film drama, film dokumenter, dan lain-lain.

Integrated Marketing Communication. Berhasil atau tidaknya sebuah kegiatan komunikasi secara efektif ditentukan oleh strategi sosialisasi dengan cara pengkonsumsiannya. Strategi komunikasi merupakan paduan dari perencanaan komunikasi dan manajemen komunikasi untuk dapat mencapai satu tujuan. Namun untuk mencapai tujuan tersebut, strategi tidak berfungsi sebagai peta jalan yang hanya menunjukkan arah saja, tetapi harus menunjukkan bagaimana taktik operasionalnya. Strategi komunikasi adalah metode yang dilakukan untuk keberhasilan proses penyampaian pesan oleh seseorang kepada orang lain untuk memberitahu, mempengaruhi, atau mengubah sikap, pendapat, perilaku, baik secara langsung dengan lisan maupun tidak langsung dengan melalui media (Effendy, 2013).

Strategi komunikasi dapat diimplementasikan melalui komunikasi pemasaran terpadu atau integrated marketing communication (IMC). McHugh (2010) berpendapat komunikasi pemasaran terpadu (IMC) adalah aktivitas untuk mengkombinasikan semua alat promosi menjadi satu strategi promosi yang menyeluruh dan terpadu. Asosiasi agensi periklanan di Amerika mendefinisikan integrated marketing communication sebagai sebuah konsep yang dikenal sebagai nilai tambah dari sebuah perencanaan yang komprehensif yang mengevaluasi peranan strategi dari berbagai disiplin komunikasi dan mengkombinasikan disiplin tersebut secara jelas, konsisten dan mencapai dampak komunikasi yang maksimal (Shakeel-UI Rehman dan M. Syed Ibrahim, 2011).

Menurut Kotler dan Keller (2012) terdapat delapan instrumen utama dalam IMC yang dapat mengoptimalkan efektifitas komunikasi pemasaran yang dapat dilakukan yaitu:

(1) Advertising, atau iklan merupakan salah satu bentuk promosi yang paling dikenal dan dibahas karena jangkauannya yang luas (Morissan, 2010). Iklan menjadi hal yang penting bagi perusahaan baik barang atau jasa karena iklan merupakan medium di mana mereka bisa mempromosikan produk mereka kepada masyarakat luas. Terdapat tiga tujuan utama dari periklanan, yaitu menginformasikan, membujuk, dan mengingatkan konsumen akan suatu produk. Pembuatan media iklan harus didasarkan pada tujuan penyampaian pesan yang meliputi target audiens yang dituju, media apa yang digunakan, kapan iklan ditayangkan dan berapa lama durasi tayangan iklan; 
(2) Sales Promotion, atau promosi penjualan adalah bentuk persuasi langsung melalui penggunaan berbagai insentif yang dapat diukur untuk merangsang pembelian produk dengan segera dan atau meningkatkan jumlah barang yang dibeli pelanggan. Sedangkan McHugh (2010) mendefinisikan promosi penjualan sebagai alat promosi yang menstimulasi pembelian konsumen melalui aktivitas jangka pendek. Promosi Penjualan atau sales promotion secara umum dapat dibedakan menjadi dua bagian, yaitu promosi penjualan yang berorientasi kepada konsumen yang biasanya dapat ditandai dengan program pemberian kupon, potongan harga, pengadaan kontes, atau pemberian sampel kepada para konsumen tingkat akhir, dan promosi penjualan yang berorientasi kepada perdagangan dimana promosi ini ditujukan pada pihak yang menjadi perantara perusahaan seperti distributor dan pengecer;

(3) Personal Selling, adalah presentasi dan promosi barang dan jasa secara tatap muka. Menurut Adisaputro (2010), penjualan personal merupakan cara paling efektif pada tahapan akhir suatu proses pembelian, khususnya mampu membangun referensi dari pembeli, meningkatkan kepercayaan pembeli dan mendesak pembeli untuk melakukan aksi pembelian. Penjualan personal berfungsi untuk mencari prospek, menentukan sasaran, mengkomunikasikan, menjual, melayani, mengumpulkan informasi dan mengalokasikan informasi tersebut;

(4) Public Relation, atau Hubungan Masyarakat (Humas) merupakan elemen penting bagi tiap lembaga baik perusahaan, industri, maupun organisasi. Menurut Hermawan (2012) humas merupakan upaya komunikasi menyeluruh dari suatu perusahaan untuk mempengaruhi persepsi, opini, keyakinan, dan sikap berbagai kelompok terhadap perusahaan tersebut. Menurut Jefkins dalam Morissan (2010), terdapat begitu banyak definisi humas, namun ia sendiri memberikan batasan humas yaitu sesuatu yang merangkum kesuluruhan komunikasi yang terencana, baik itu ke dalam maupun ke luar antara suatu organisasi dengan semua khalayaknya dalam rangka mencapai tujuan-tujuan spesifik yang berlandaskan pada saling pengertian. Menurutnya, humas pada intinya senantiasa berkenaan dengan kegiatan penciptaan pemahaman melalui pengetahuan, dan melalui kegiatan-kegiatan tersebut diharapkan akan muncul suatu dampak yakni perubahan yang positif. Humas juga memiliki peranan dalam membentuk dan mempertahankan citra suatu perusahaan, sehingga masyarakat akan melihat atau menilai perusahaan tersebut sesuai dengan apa yang dicitrakan oleh humas itu sendiri;

(5) Direct Marketing, adalah upaya perusahaan atau organisasi untuk berkomunikasi secara langsung dengan calon pelanggan sasaran dengan maksud untuk menimbulkan tanggapan atau transaksi penjualan (Morissan, 2010). Pemasaran langsung dapat menggunakan sejumlah saluran untuk menjangkau calon pelanggan, seperti dengan memasarkan melalui surel, surat langsung, pemasaran katalog, telemarketing, TV interaktif, kios dan situs web;

(6) Internet marketing, marketing adalah segala jenis pemasaran yang dilakukan melalui internet. Aktivitas melalui Internet marketing dapat memberikan peluang untuk mewujudkan kegiatan baru dalam pemasaran tradisional dari non elektronic bergeser menjadi electronic platform (Sutejo, 2016). Internet marketing disebut juga sebagai pemasaran-i, web marketing, online marketing, e-marketing atau e-commerce. Internet marketing memberikan berbagai kemudahan bagi perusahaan khususnya dalam berinteraksi dengan pelanggan, 
menyampaikan informasi ke pelanggan, membantu memahami pelanggan dengan lebih baik, membangun hubungan dan mempertahankan hubungan dengan pelanggan, memfasilitasi pertukaran ide, produk dan pelayanan untuk memenuhi kebutuhan dan keinginan pasar.

Dalam memasarkan produk dan jasa pada era saat ini media online bisa menjadi pilihan yang banyak digunakan oleh para produsen untuk memasarkan produknya baik berupa barang maupun jasa. Menurut Sukma dan Made dalam Panduan Pengelolaan Desa Wisata (2015) pemasaran online dapat memberikan banyak manfaat dan bisa menjadi lebih sukses dibandingkan dengan pemasaran offline, termasuk manfaat yang diperoleh dalam pemasaran paket wisata suatu desa wisata, yaitu: yang pertama dapat melakukan perubahan dengan cepat dalam artian pemasang iklan dapat merubah dengan cepat jika terjadi kesalahan dan dapat merubah grafis atau kata-kata secara cepat apabila. Kedua, dapat menelusuri hasil secara real-time, dalam hal ini pemasaran online memungkinkan pemasang iklan untuk melacak hasil secara real-time menggunakan analisis secara online dalam kinerja kampanye pemasaran yang dilakukan. Ketiga, dapat menargetkan demografis tertentu dalam iklan baik dalam tingkat pendapatan, pendidikan, usia, gender, lokasi dan pekerjaan target pasar. Keempat, banyak pilihan dalam pemasaran online seperti menggunakan audio, video, blogging, email, media sosial, dan news letter yang sedang berlangsung. Kelima yaitu kemampuan konversi instan, dalam hal ini dapat mengubah pelanggan secara instan;

(7) Word of mouth marketing (WOMM). Menurut Kotler dan Keller, word of mouth marketing atau pemasaran dari mulut ke mulut yaitu komunikasi lisan, tertulis dan elektronik antar masyarakat yang berhubungan dengan keunggulan atau pengalaman membeli atau menggunakan produk atau jasa. Kotler (2010) berpendapat model promosi dari mulut ke mulut akan lebih meyakinkan karena didasari oleh adanya pengalaman pembelian, serta tidak membutuhkan biaya yang besar.

Desa Wisata. Adanya pengembangan wisata desa merupakan dampak dari keinginan masyarakat untuk melakukan model pariwisata yang bervariasi. Penat dengan hiruk pikuk kota dan ingin kembali dekat dengan alam serta ingin menemukan atau mempelajari kearifan lokal seringkali menjadi alasan para wisatawan memilih untuk berlibur ke desa wisata. Terbentuknya desa wisata biasanya didasari oleh adanya objek atau sarana yang mendukung kegiatan kepariwisataan dan memiliki potensi pariwisata. Menurut Chafid Fandeli (2002), desa wisata ialah suatu wilayah pedesaan yang menawarkan keseluruhan suasana yang mencerminkan keaslian desa, baik dari segi kehidupan sosial budaya, adat istiadat, aktifitas keseharian, arsitektur bangunan, struktur tata ruang desa, serta potensi yang mampu dikembangkan sebagai daya tarik wisata, misalnya: atraksi, makanan dan minuman, cinderamata, penginapan, dan kebutuhan wisata lainnya.

Menurut Hadiwijoyo (2012) suatu desa bisa disebut desa wisata bila memiliki beberapa kriteria sebagai berikut: (1) aksesibilitasnya baik, sehingga mudah dikunjungi wisatawan dengan menggunakan berbagai jenis alat transportasi; (2) memiliki objek-objek menarik baik berupa alam, seni budaya, legenda, makanan lokal dan sebagainya; (3) mMasyarakat dan aparat desa menerima dan memberikan dukungan yang tinggi terhadap desa wisata serta para wisatawan yang datang ke desanya; (4) keamanan di desa yang terjamin; (5) tersedia akomodasi, telekomunikasi, serta tenaga kerja yang memadai; (6) beriklim sejuk atau dingin; (7) berhubungan dengan objek wisata lain yang sudah dikenal oleh masyarakat. 
Terdapat tiga karakteristik utama yang perlu diperhatikan dalam upaya pengembangan suatu objek wisata tertentu agar menarik dan dikunjungi banyak wisatawan. Karakteristik tersebut adalah (1) Something to see, maksudnya di tempat tersebut harus ada objek wisata dan atau atraksi wisata yang berbeda dengan apa yang dimiliki oleh daerah lain sehingga memiliki daya tarik yang khusus dan unik; (2) Something to do, maksudnya di tempat tersebut harus terdapat kegiatan yang bisa dilakukan dan disediakan pula fasilitas rekreasi atau amusement yang dapat membuat wisatawan betah tinggal lebih lama di tempat itu; (3) Something to buy, di tempat tersebut ada fasilitas berbelanja, terutama souvenir dan kerajinan tangan rakyat sebagai oleh-oleh khas.

\section{METODE PELAKSANAAN}

Pelaksanaan pengabdian kepada masyarakat ini menerapkan metode penelitian kualitatif dengan pendekatan deskriptif: memaparkan implementasi CBT dan IMC pada Desa Tanjung Kecamatan Juwiring dalam mewujudkan konsep Desa Wisata. Menurut Mukhtar (2013) metode penelitian deskriptif kualitatif adalah sebuah metode yang digunakan peneliti untuk menemukan pengetahuan atau teori terhadap penelitian pada satu waktu tertentu.

Data diperoleh melalui metode wawancara mendalam untuk memperoleh data seputar kondisi Desa Wisata Tanjung. Untuk itu disiapkan beberapa pertanyaan sehingga yang diperoleh masih dalam batasan dan tetap fokus pada inti permasalahan. Wawancara mendalam dilakukan pada elemen yang berkaitan dengan Desa Tanjung Kecamatan Juwiring. Informan dalam kajian ini adalah Lurah dan Ketua RW Desa Tanjung Kecamatan Juwiring, serta dua orang pengrajin payung muto.

\section{HASIL DAN PEMBAHASAN}

Payung lukis Juwiring yang diproduksi oleh masyarakat Desa Tanjung telah ada sejak tahun 1800 -an. Payung lukis pada mulanya digunakan sebagai hiasan untuk acara adat dan hari-hari penting tertentu. Hal itu kemudian berpengaruh pada pola hias payung, yakni memiliki motif gelap dan polos. Namun, saat ini payung lukis telah bertransformasi dan dapat digunakan sebagai hiasan atau dekorasi di tempat-tempat umum sehingga corak dan warnanya menjadi lebih beragam.

Kerajinan payung lukis dikelola oleh warga dalam rangka pelaksanaan program desa wisata di Desa Tanjung, Kecamatan Juwiring. Kecamatan Juwiring merupakan salah satu kecamatan di Kabupaten Klaten yang terkenal dengan kerajinan payung lukis (payung muto). Lokasi industri kerajinan payung Juwiring yang dikelilingi oleh area persawahan menghadirkan suasana desa dengan keasrian alam dapat menambah daya tarik untuk desa wisata ini. Target audiens Desa Wisata Tanjung adalah para pelaku usaha yang ingin membeli payung lukis dalam jumlah besar, wisatawan yang memiliki ketertarikan dengan wisata budaya khususnya seputar pembuatan kerajinan payung lukis, dan memiliki ketertarikan terhadap sejarah Indonesia, khususnya Jawa. 
Market Analysis. Dari tahun ke tahun, pembangunan desa wisata di Indonesia terus mengalami peningkatan. Perkembangan ini seiring dengan adanya kebijakan dana desa yang berlaku sejak diterbitkannya UU Nomor 6 Tahun 2014 tentang Desa. Suntikan dana dari pemerintah pusat meningkatkan gairah pemerintah desa untuk mengalokasikan dana desa untuk sektor wisata. Selain itu, pembangunan desa wisata juga didasari atas kearifan lokal yang dimiliki oleh masing-masing daerah. Setiap desa memiliki ciri khas dan nilai jualnya masing-masing yang autentik, seperti sentra kerajinan, wisata alam, wisata adat, hingga wisata sejarah. Kearifan lokal tersebut menjadi nilai dasar bagi masyarakat dalam membangun desa wisata yang berkelanjutan dan dikenal secara luas.

Sampai saat ini, tren desa wisata di Indonesia mengalami perubahan dan pergerakan naik turun. Desa wisata berbasis sentra kerajinan lokal menjadi salah satu tren yang ramai diterapkan di berbagai daerah hingga saat ini. Para pengrajin di desa setempat saling bekerja sama untuk dapat menciptakan produk khas yang bisa diekspor ke daerah luar hingga mancanegara. Selain itu, pemerintah desa dan masyarakat setempat juga mengembangkan fasilitas dan aksesibilitas desa agar dapat dikunjungi oleh turis yang ingin belajar langsung bersama pengrajin lokal. Tren tersebut diikuti oleh berbagai desa yang memiliki produk khas daerah tetapi belum memiliki kesadaran untuk menjualnya ke pasar yang lebih luas.

Pembangunan desa wisata yang semakin digencarkan oleh masyarakat dan didukung oleh Kemenparekraf mendorong potensi yang besar bagi desa di Indonesia, termasuk Desa Tanjung. Kerajinan payung lukis merupakan suatu kearifan lokal yang dapat menarik wisatawan untuk berkunjung dan membeli produk yang dijual. Nilai sejarah yang kuat juga dapat menjadi ciri khas sehingga semakin menarik minat wisatawan, terutama yang menyukai sejarah. Tidak hanya itu, lingkungan di Desa Tanjung juga terbilang masih asri sehingga dapat memanjakan masyarakat yang datang dari kota-kota besar. Dengan demikian, potensi yang dapat dikembangkan oleh Desa Wisata Tanjung beragam, mulai dari sentra kerajinan lokal, wisata sejarah, hingga lingkungan desa yang asri.

Berdasarkan data yang tersedia, terdapat tiga desa di Kabupaten Klaten yang secara produktif memproduksi payung lukis. Tiga desa tersebut yaitu Tanjung, Kenaiban, dan Kwarasan. Sedangkan kompetitor desa wisata yang berbasis sentra kerajinan, terdapat banyak desa di wilayah Jateng-DIY yang sudah menjalankan program tersebut. Beberapa diantaranya ialah kerajinan bambu di Desa Brajan (Sleman, Yogyakarta), kerajinan gerabah di Desa Melikan (Klaten, Jawa Tengah) dan Dusun Klipoh (Magelang, Jawa Tengah), dan berbagai desa lainnya.

\section{Analisis SWOT}

Strength. Berikut ini kekuatan yang dimiliki produk kerajinan payung muto: (1) memiliki ciri khas unik dan hanya dijumpai di wilayah Juwiring; (2) kerajinan payung muto mengandung nilai sejarah dan budaya yang tinggi; (3) kerajinan payung muto menggunakan bahan ramah lingkungan dan proses pengerjaannya secara manual sehingga kualitas dan keunikan motifnya selalu terjaga; (4) payung hias dapat dipesan sesuai dengan keinginan dan kebutuhan dari pembeli: ukuran, corak atau motif dan bahan dasar yang digunakan; (5) harga terjangkau; (6) lokasi desa wisata memiliki aksesibilitas yang mudah dijangkau; (6) lokasi Desa Tanjung memiliki banyak area persawahan menjadikan suasana desa asri dan dapat dimanfaatkan untuk pengembangan desa wisata dengan objek agrowisata; (7) Desa Wisata 
Tanjung memenuhi tiga karakteristik yang harus dipenuhi dalam pengembangan objek wisata.

Weakness. Adapun kekurangan yang dimiliki Desa Tanjung adalah: (1) belum terdapat fasilitas yang secara terpadu menjadi sentra pameran dari payung muto yang dihasilkan oleh para pengrajin; (2) Desa wisata tanjung dan kerajinan payung muto belum dipasarkan atau dipromosikan dengan optimal, sehingga brand awareness masyarakat terhadap objek wisata ini masih tergolong rendah; (3) terbatasnya modal para pengrajin untuk memproduksi payung muto; (4) bahan baku kertas untuk pembuatan payung susah didapat; (5) adanya monopoli pasar sehingga harga jual payung muto yang dijual pengrajin pada stakeholder terkait rendah; (6) mayoritas pengrajin payung muto sudah berusia lanjut sehingga berpengaruh pada estimasi waktu dan keterbatasan produksi.

Opportunity. Peluang yang dimiliki Desa Tanjung adalah: (1) Desa Wisata Tanjung memiliki potensi wisata budaya melalui kerajinan payung muto dan potensi agrowisata melalui kondisi geografisnya. Apabila dikelola dengan optimal, maka dapat berkembang menjadi desa wisata yang lebih baik; (2) adanya program pembentukan desa wisata yang dilakukan oleh Kemenpar. Hal ini dapat dimanfaatkan oleh Desa Wisata Tanjung untuk mengikuti program tersebut dan memperoleh pendanaan serta pembinaan; (3) minat masyarakat terhadap wisata yang tinggi, sehingga kesempatan untuk mendapatkan konsumen sasaran juga cukup tinggi; (4) perkembangan media daring dan e-commerce membuat Desa Wisata Tanjung dan kerajinan payung muto menjadi dapat dipasarkan dengan jangkauan yang lebih luas.

Threat. Ancaman ke depan yang dihadapi Desa Tanjung adalah: (1) tidak adanya regenarasi pengrajin payung muto; (2) kelangkaan bahan baku, sehingga para pengrajin harus mencari penyuplai bahan baku lain; (3) adanya desa wisata yang juga berlokasi di daerah Klaten, Yogyakarta dan Solo Raya; (4) peningkatan biaya produksi yang tidak dibersamai dengan peningkatan hasil jual.

Berdasarkan uraian analisis situasi dan SWOT yang telah dibahas sebelumnya, maka objektif dan konsep strategi kreatif serta media yang diimplementasikan melalui IMC dibahas sebagai berikut:

Objektif, meliputi: (1) meningkatkan brand awareness di kalangan target audiens terhadap brand payung muto sebagai kerajinan payung hias dengan nilai historis dan budaya yang tinggi; (2) meningkatkan brand awareness di kalangan target audiens terhadap brand Desa Wisata Tanjung sebagai desa wisata yang memiliki objek wisata budaya dan agrowisata; (3) memperluas pangsa pasar kerajinan payung muto.

Scheduling Strategy. Setelah menentukan objektif, tahap selanjutnya ialah penyusunan strategi atau scheduling strategy yang dilakukan untuk mencapai objektif dalam pengimplementasian IMC. Fase-fase pencapaian objektif dari IMC ini dibagi menjadi tiga tahap seperti berikut: (1) Brand Awareness. Untuk membangun dan meningkatankan brand awareness target audiens, maka akan dilakukan digital campaign melalui platform Facebook dan Instagram. Digital campain ini akan dilakukan selama tiga bulan; (2) Engagement. Untuk memperkenalkan kembali, mempertahankan loyalitas, serta dalam rangka untuk menarik minat stakeholder membeli atau berinvestasi pada kerajinan payung muto dan atau Desa 
Wisata Tanjung, diadakan event yang termasuk dalam bagian Public Relation; (3) Sustain. Media sosial dimanfaatkan dalam menjaga interaksi dan mempertahankan loyalitas dengan konsumen terhadap payung muto dan Desa Wisata Tanjung. Media Sosial juga dimanfaatkan sebagai media recall brand terkait.

Dari hasil riset awal yang dilakukan dengan beberapa stakeholders Desa Tanjung, ditemukan beberapa masalah yang menjadi fokus utama dalam pengembangan desa wisata ini. Masalah utama yang terjadi adalah kurangnya pemerataan konsumen antara pengrajin besar dan pengrajin kecil yang ada. Karena pengelolaan kerajinan payung ini masih dipegang secara perorangan, maka masih terdapat kesenjangan pemasaran sehingga konsumen hanya membeli payung muto melalui pengrajin besar, sedangkan pengrajin kecil hanya menjual hasil kerajinannya pada pengrajin besar. Hal ini menyebabkan pemusatan penjualan payung muto dan adanya perbedaan harga jual. Hal ini juga menyebabkan hanya pengrajin besar yang produknya diketahui oleh masyarakat luas, sedangkan pengrajin kecil tidak.

Untuk mengatasi masalah tersebut, Pemerintah Desa setempat dapat membangun galeri kreatif yang difungsikan sebagai tempat pameran dan penjualan payung muto yang dihasilkan oleh warga setempat. Galeri kreatif ini nanti akan dijadikan sebagai lokasi pameran kerajinan payung muto serta sebagai sentra oleh-oleh yang dikelola secara kolektif. Dengan adanya galeri ini diharapkan para wisatawan atau konsumen bisa lebih objektif dalam memilih produknya bukan hanya karena nama semata. Selain itu juga bisa memacu para pengrajin untuk lebih kreatif dan inovatif lagi dalam menciptakan corak, serta terus meningkatkan kualitas payungnya sehingga dapat bersaing secara sehat. Untuk dapat merealisasikan hal ini diperlukan kerja sama yang baik antara pemerintah desa dan pengrajin.

Masalah selanjutnya ialah kurangnya exposure terhadap kerajinan payung muto dan Desa Wisata Tanjung, sehingga brand awareness masyarakat khususnya target konsumen masih kurang. Kerajinan payung muto dan Desa Wisata Tanjung sendiri belum memiliki brand image yang kuat karena sebelumnya belum pernah dikelola dengan optimal. Oleh karena itu, diperlukan pembentukan brand image yang tepat untuk membranding dan menyertakannya di tiap-tiap promosi atau kegiatan pemasaran yang dilakukan.

Setelah mengidentifikasi permasalahan yang ada serta menjabarkannya dalam Big Idea, maka tahap selanjutnya yang harus ditentukan adalah Key Message. Key Message adalah isi pesan yang ingin disampaikan dan juga untuk menjembatani maksud dan tujuan kepada publik. Key message yang ingin disampaikan kepada target audiens adalah bahwa kerajinan payung muto di Desa Wisata Tanjung Kecamatan Juwiring merupakan warisan budaya Indonesia yang memiliki nilai historis yang tinggi. Pesan ini kemudian dikemas dalam tajuk "Jelajah Rupa-Rupa Budaya Indonesia", yang sekaligus dijadikan sebagai tagline dari Desa Wisata Tanjung itu sendiri.

“Jelajah Rupa-Rupa Budaya Indonesia" dipilih sebagai tagline dari Desa Wisata Tanjung karena dianggap mampu merepresentasikan apa yang ada di desa ini. Desa Wisata Tanjung merupakan sentra kerajinan payung muto, yang merupakan salah satu budaya asli Indonesia. Berwisata di desa ini, maka wisatawan dapat menjelajahi rupa-rupa budaya berbentuk kerajinan payung muto yang memiliki berbagai warna dan corak yang unik, serta kental dengan nuansa Indonesia. 
Marketing Communication Tools yang digunakan adalah (1) Advertising dengan objective berupa awareness: untuk meningkatkan kesadaran target konsumen dengan adanya brand payung muto dan Desa Wisata Tanjung dengan digital campaign yang ada; recall, untuk membangiktan kembali ingatan target audiens terkait keberadaan kerajinan payung muto dan Desa Wisata Tanjung melalui digital campaign yang dilakukan.

Brand awareness dari kerajinan payung muto dan Desa Wisata Tanjung yang masih kurang oleh target audiensnya, pemaparan iklan kepada mereka akan membuat awareness audiens meningkat dan mengetahui keberadaan kerajinan payung muto dan Desa Wisata Tanjung. Selain itu melalui iklan juga dapat menstimulasi ingatan mereka terhadap produk ini. Adapun iklan yang digunakan ialah digital ad dan print ad, ditujukan kepada target audiens dari kerajinan payung muto dan Desa Wisata Tanjung seperti yang telah disebutkan pada analisis situasi.

Untuk digital ad, digunakan Facebook Ad dan Instagram Ad. Facebook dan Instagram dipilih sebagai platform digital Ad karena dua media sosial tersebut menjadi media sosial yang umum digunakan oleh masyarakat Indonesia. Per Januari 2020, di kalangan pengguna internet di Indonesia yang berusia 16-64 tahun, Facebook menjadi media sosial ketiga dan Instagram di posisi keempat sebagai media sosial yang paling sering digunakan, dengan masing-masing total pengguna yakni sebanyak $84 \%$ dan $79 \%$ dari total 160 juta pengguna media sosial (We Are Social \& Hootsuite, 2020). Oleh karena itu, Facebook dan Instagram menjadi pilihan platform digital ad yang dirasa tepat karena target audiens dari kerajinan payung muto dan Desa Wisata Tanjung berada pada rentang usia pengguna media sosial tersebut dengan jumlah persentase yang cukup tinggi. Facebook dan Instagram Ad juga dipilih karena proses pembuatan, pengelolaan dan pemantauan serta evaluasinya cenderung mudah dilakukan.

Untuk print ad, menggunakan banner yang dipasang pada wilayah yang strategis seperti perbatasan antar kabupaten/kota dan pusat keramaian. Pada print ad, dicantumkan informasi seputar lokasi dan keunikan desa wisata tanjung. Pemasangan print ad, selain untuk meningkatkan brand awareness, juga dilakukan sebagai upaya brand recall;

(2) Direct Marketing dengan objective berupa engaging, untuk berinteraksi langsung dengan konsumen yang sudah pernah berhubungan dengan pengrajin payung muto dengan tujuan untuk menjaga loyalitas; selling, untuk meningkatkan penjualan produk, dan recall. untuk membangiktan kembali ingatan target audiens terkait keberadaan kerajinan payung muto dan Desa Wisata Tanjung melalui digital campaign yang dilakukan.

Direct marketing adalah strategi melakukan pemasaran secara langsung kepada audience secara langsung, untuk bisa meningkatkan jumlah pembelian. Direct marketing dapat dilakukan dengan direct selling dengan cara memberikan penawaran kepada konsumen yang sebelumnya sudah pernah membeli produk terkait. Direct marketing bisa dilakukan melalui komunikasi personal seperti surel dan SMS. Selain memberikan penawaran, juga dapat dilakukan pemberian informasi seputar kerajinan payung muto dan Desa Wisata Tanjung seperti informasi tentang produk baru, promo yang ada, event yang diselenggarakan di Desa Wisata Tanjung atau partisipasi kerajinan payung muto pada platform lain; 
(3) Public Relation, dengan objective: membangun dan menjaga citra kerajinan payung muto dan Desa Wisata Tanjung kepada khalayak umum; memperkuat brand loyalty payung muto dan Desa Wisata Tanjung dengan audiens setianya; membangun brand image dari payung muto dan Desa Wisata Tanjung kepada khalayak umum;

(4) Media Strategy. Marketing communication tools berupa PR ditargetkan untuk seluruh target audiens dari kerajinan payung muto dan Desa Wisata Tanjung. Langkah yang dapat ditempuh ialah melakukan event berupa pameran seni yang memamerkan hasil kerajinan payung muto dan kelas melukis payung hias, kemudian bekerja sama dengan media-media lokal seperti akun Explore Jogja, Explore Solo, dan Explore Solo untuk meliput kegiatan. Media-media tersebut dipilih karena sesuai dengan segmentasi target audiens yang dimiliki oleh kerajinan payung muto dan Desa Wisata Tanjung. Bekerjasama dengan media yang telah disebutkan dapat membantu meningkatkan brand awareness dari kerajinan payung muto dan Desa Wisata Tanjung karena media-media tersebut memiliki cakupan persebaran informasi yang luas.

Selain mengadakan event sendiri dan melibatkan pelaku media, dapat juga dilakukan kerjasama dengan promotor pameran atau festival kesenian dan budaya seperti ARTJOG atau Biennale. Ikut serta dalam pameran atau festival yg dilakukan di luar daerah Juwiring dapat menjadi sarana mengenalkan kerajinan payung muto dan Desa Wisata pada khalayak publik yang lebih luas;

(5) Media Strategy, khususnya media baru, kini telah menjadi platform yang umum digunakan untuk melakukan pemasaran dan promosi suatu produk. Jangkauan yang luas, fitur yang beragam, dan budget yang lebih hemat menjadi beberapa alasan mengapa media baru kerap kali menjadi pilihan bagi pelaku usaha untuk memasarkan produknya. Pada konsep IMC yang diperuntukkan kerajinan payung muto dan Desa Wisata Tanjung ini, media baru, yang secara lebih spesifik ialah Facebook dan Instagram, akan digunakan sebagai media resmi untuk pembuatan aku dan digital campaign dari kerajinan payung muto dan Desa Wisata Tanjung.

Objective yang didapat adalah: awareness, bertujuan untuk meningkatkan awareness kepada target audiens terhadap keberadaan brand payung muto dan Desa Wisata Tanjung; recalling, diharapkan dengan adanya interaksi dari sosial media kepada target audiens dapat memberikan kesan yang tertinggal dan membuat ingatan mereka tentang payung muto dan Desa Wisata Tanjung lebih kuat.

Akun sosial media resmi akan menjadi media yang berperan penting dalam meningkatkan awareness dari kerajinan payung muto dan Desa Wisata Tanjung. Akun sosial media resmi ini akan diberi nama "Desa Wisata Tanjung". Adapun konten yang akan diposting ialah sebagai berikut: Showcasing product; Campaign \#JelajahRupaRupaBudayalndonesia; Interaktif Content (Quiz); Testimonial Content; Call to Action.

Showcasing Product content adalah konten yang menunjukkan visual product yang dijual oleh Desa Wisata Tanjung, yaitu berupa kerajinan payung muto dan pemandangan alam dalam bentuk agrowisata yang masih asri, bertujuan menunjukkan nilai estetika dari segi photography product sehinggaa audiens akan tertarik untuk melakukan wisata dan membeli 
kerajinan payung muto. Selain itu konten ini juga bertujuan untuk meningkatkan awareness dan brand image dikarenakan nilai elegan yang terdapat dalam visual foto nya.

Campaign \#JelajahRupaRupaBudaya Indonesia adalah konten yang bertujuan untuk menyampaikan pesan kepada audiens bahwa Desa Wisata Tanjung memiliki wisata budaya berbentuk kerajinan payung muto yang memiliki berbagai warna dan corak yang unik.

Interaktif Content (Quiz) adalah konten dimana kita mengajak target audiens untuk berinteraksi dengan sosial media. Konten ini bertujuan untuk menjadikan dan sekaligus memberikan informasi kepada audiens bahwa mereka bisa melakukan komunikasi dua arah dengan kami melalui sosial media, yang pada akhirnya diharapkan sosial media akan menjadi platform yang membuat target audiens tertarik untuk membeli dan juga membagikan (share) kepada teman teman mereka.

Testimonial content adalah konten yang menunjukkan pada khalayak umum mengenai feedback langsung dari para pembeli produk payung muto atau wisatawan Desa Tanjung. Konten ini bertujuan memberikan informasi kepada target audiens mengenai kejadian nyata yang dirasakan oleh pembeli lainnya. Hal ini juga diharapkan dapat memberikan dampak pada calon buyer pada tahapan interest menjadi decision.

Konten-konten ini akan menjadi konten dalam digital campaign yang dilakukan selama tiga bulan, dengan intensitas posting minimal tiga konten selama seminggu. Hal ini dimaksudkan untuk melakukan digital campaign dengan objektif berupa peningkatan brand awareness. Pengaruh dari digital campaign yang bisa digolongkan sebagai Internet marketing ini diharapkan bisa mendapat hasil signifikan terhadap brand awareness. Semua ini dilatarbelakangi oleh hubungan brand awareness terhadap frekuensi seberapa sering suatu informasi atau pesan tentang suatu produk diterima dan dikaji oleh konsumen dari suatu perusahaan (Azaria, 2014).

Agar jangkauan pasar dari kerajinan payung muto dapat menjadi luas, maka dapat dilakukan melalui internet marketing. Memanfaatkan platform-platform e-commerce seperti tokopedia dan shopee dengan membuat akun penjualan resmi dapat menjadi alternatif dalam memasarkan produk ini.

Selain membutuhkan strategi pemasaran terpadu yang baik, visualisasi dari konsep juga menjadi hal yang perlu dieksekusi dengan baik. Untuk itu, diperlukan kreatifitas dalam memproduksi konten-konten promosi, baik untuk keperluan promosi digital, maupun nondigital. Uraian tentang konsep penggunaan IMC pada artikel ini kemudian dapat dijadikan sebagai rujukan dalam implementasi perwujudan Desa Wisata Tanjung.

\section{SIMPULAN}

Terdapat beberapa masalah yang menghambat pengembangan Desa Wisata Tanjung. Peneliti membuat strategi kreatif dan media dengan untuk mengatasi masalah yang berkembang di Desa Tanjung. Melalui pendekatan tersebut, ditemukan beberapa cara, seperti pembangunan galeri kreatif untuk memamerkan produk payung muto milik warga, pembentukan brand 
image untuk mem-branding dan mempromosikan produk-produk Desa Wisata Tanjung. Lebih jauh, peneliti melakukan analisis lebih dalam dengan menggunakan Integrated Marketing Communication (IMC) dengan harapan Desa Wisata Tanjung memiliki brand image dan brand awareness yang tinggi di tengah masyarakat.

\section{DAFTAR PUSTAKA}

Adisaputro, G. (2010). Manajemen Pemasaran: Analisis untuk Perancangan Strategi Pemasaran. Yogyakarta: UPP STIM YKPN.

Agus, H. (2012). Komunikasi Pemasaran. Jakarta: Erlangga

Azaria, P.A. (2014). Internet marketing terhadap pembentukan word of mouth dan efektivitas iklan dalam meningkatkan brand awareness. Jurnal Administrasi Bisnis, 13(1).

Brets, R. (2008). Media Pembelajaran. Jakarta: Gramedia Pustaka Utama.

Charles. F.F. (2013). Creative Strategy: A Management Perspective. Journal of Advertising, 12(4).

Effendy, O.U. (2013). Ilmu Komunikasi : Teori dan Praktek. Bandung: Remaja Rosdakarya

Gilson, C., Harold, W.B. (1980). Advertising: Concepts \& Strategies. USA: Rand McNally.

Hadiwijoyo, S.S. (2012). Perencanaan Pariwisata Perdesaan Berbasis Masyarakat (Sebuah Pendekatan Konsep). Yogyakarta: Graha Ilmu

Happer, C., \& Philo, G. (2013). The Role of the Media in the Construction of Public Belief and Social Change. Journal of Social and Political Psychology, 321-336.

Hermawan, A. (2012). Komunikasi Pemasaran. Jakarta: Erlangga.

Kasali, R. (1995). Manajemen Periklanan, Konsep dan Aplikasinya di Indonesia. Jakarta: PT. Pustaka Utama Grafiti.

Kotler, Keller. (2012). Manajemen Pemasaran Edisi 12. Jakarta: Erlangga

Lubis, Z., Osman, A. (2014). Indonesian Tourism Sector: A Potential Sector That Has Not Been Optimized. Australian Journal of Basic and Applied Sciences, 8(23): 286-290.

Made. A, \& Sukma, A. (2015). Panduan Pengelolaan Desa Wisata Berbasis Potensi Lokal. Bali: Konsorsium Riset Pariwisata Universitas Udayana.

Malik, M. E. (2013). Importance of brand loyalty in assessing purchase intentions of customer. International Journal of Business and Social Science, 4(5).

McHugh, J.M. (2010). Pengantar Bisnis. Jakarta: Salemba Empat.

Mihart, C. (2012). Marketing Communication on Consumer Behaviour: Effects on Consumer Decision - Making Process. International Journal of Marketing Studies, 4(2).

Morissan. (2010). Periklanan Komunikasi Pemasaran Terpadu. Jakarta: Kencana

Oktaviani, F., Diki, R. (2018). Implementasi Digital Marketing dalam Membangun Brand Awareness. PRofesi Humas. 3(1). 1-20

Rehman, S.U., Ibrahim, M.S. (2011). Integrated Marketing Communication and Promotions. India: Vol.1, No.4: 187.

Setiawan, N.A. (2014). Strategi Promosi dalam Pengembangan Pariwisata Lokal di Desa Wisata Jelekong. Trikonomika. 13(2): 184-19

Soebagyo. (2012). Strategi Pengembangan Pariwisata di Indonesia. Jurnal Liquidity, 1(2), 153 158.

Sutejo, B. S. (2016). Internet marketing: konsep dan persoalan baru dunia pemasaran. Jurnal Manajemen, 6(1). 
Suyanti, D.W. (2013). Potensi Desa Melalui Pariwisata Pedesaan. Jurnal Ekonomi dan Bisnis, 12(1): 33-36. 